\title{
Utilizing Local Content: Strategy to Get Closer to the Consumers through Suprastructure and Positioning Analysis
}

\author{
N S Wrihatni \\ Javanese Study Program, Department of Linguistic Faculty of Cultural Science \\ University of Indonesia \\ novikastriwrihatni@gmail.com
}

\begin{abstract}
This article explained about the suprastructure and positioning of Kopi ABC Susu advertisement which uses Sundanese. The result of the research showed that the advertisement is one of the marketing strategy of a product to get close to the consumer at certain market segmentation. Positioning by translating to Sundanese became the main case to overcome the difference on the consumer's culture. It was carried out to emphasize the brand positioning of the product among the similar products. The theory used to analyze the suprastructure includes Renkema (2004) and Kres and van Leuweeun (2006), while the analysis for positioning was based on Kasali (1998), Leech (1966) and Brierley (1995). The research was carried out as qualitative method, thus the data is interpreted as is.
\end{abstract}

Keywords: Local Content; Culture; Brand Positioning; Sundanese; Positioning; Advertisement

\section{INTRODUCTION}

Advertisement is a method of communication characterised as single directional from the producers to the consumers. The communication is expected to stimulate the changes in the reader's role, from being a reader to a consumer, buyer or service user. Sometimes, the advertisement may or may not arouse the reader will. The condition where the consumer is aroused to buy or become a service user if influenced by several factors, including: informative and interesting advertisement, such as communicative text or interesting pictures [1], [2] this fact is interesting for further study, such as how an advertisement, especially with Sundanese can be informative and communicative.

The involvement of local content (Sundanee culture and language) to get close to the reader of advertisement will be interesting to be studied. Local content (Sundanese culture and 
language) is utilized to get close to the public (consumer and service user), thus the advertisement is expected to be more rapid in reaching the target.

Lately, the development of advertisement is getting more diverse, interesting, and variative. Advertisement also involve musics, images, and accompanying texts, even sometimes also display the people who has experience in using the products. Based on the types of the medium, advertisement includes the printed advertisement and electronic advertisement. So far, this research is focused on the advertisement broadcasted on the internet, nor audio-visual in the youtube page.

Etymologically, the word "iklan" (Indonesian; English: advertisement) is originally from Arabic "i'lan" which means "announcement" or "explanation" [3]-[5] In fact, the word "iklan" in Indonesian has the sinonym with "reklame" (billboard) and "advertensi" (advertising). Moreover, Jones [4] explained that the word "reklame" was adapted form Deutch "reclame" which is originally French, so does the word "advertensi" was adapted from Deutch "advertentie" which was also adapted from French "adperténsi". So far, there is no information from the linguistic perspective regarding the history of the three synonimous words in Indonesian.

Other than that, limitation on the scope of advertisement is required. The source of data in this research is the advertisement in Sundanese which could be accessed in the internet. Why the advertisement is in Sundanese? So far, the search on the electronic media showed that the advertisement in Sundanese is not as productive as the advertisement in Indonesian. The advertisement which use vernacular such as Sundanese is carried out to promote better approach of the product to the target consumer or user. This research is highlighted on the advertisement of Kopi ABC Susu which uses Sundanese obtained from the internet in visual and audio-visual formats.

\section{METHODS}

\subsection{Discourse and Advertisement}

There are a lot of coffee advertisements. However, the advertisement of Kopi ABC Susu is the only coffee advertisement which language is transliterated into Sundanese. How was the advertisement of Kopi ABC Susu translated into Sundanese? Is there any complete relationship between superstructure and positioning in the advertisement of Kopi $\boldsymbol{A B C}$ Susu? Thus, this research was carried out to observe the superstructure of the advertisement and the positioning of Kopi ABC Susu advertisement in the Sundanese. Through the description of the superstructure of Kopi $\boldsymbol{A B C} \boldsymbol{S u s u}$ advertisement, the positioning of the advertisement can be discovered.

\subsection{Limitation on the Definition of Advertisement}

Cook [6]interpreted advertisement as a genre. Cook [6] firstly explained the definition of advertisement based on Collins Concise Dictionary as "advertising is the promotion of goods or service for sale through impersonal media". Moreover, Cook[6] explained that the definition of advertisement based on the Collins Concise Dictionary is interpreted that it contain wide definition but also narrow definition. How can it be? The definition of advertisement contain a 
wide meaning, because it is not only about offering products or goods, while it is considered to have shallow meaning because the definition of advertisement is not that simple.

\subsection{Previous Research}

Rajiyem and Setianto[7] studied about the message of marketing using semiotic approach, thus the construction of culture contained in the advertisement emphasize the subordinate of female within the patriarch culture. The image displayed in the advertisement emphasize that Javanese females beside their onligation to cook and bear, they also expected to make over themshelves.

Another research carried out [8] focusing on: 1) representation of markers and signs, 2) the factors relying on the post-colonial aesthetic strength, 3) the strategy toward the policy of resistance to develop post-colonial aesthetic awareness. The theories used were semiotic and history. The data was obtained from several magazines including: Tempo, Femina, and Kartini during 2007-2009. The result showed that: 1) there were 3 representations of colonial aesthetic hegemony signs in the advertisement of comtemporer printed media in Indonesia, such as: a) western-ish or Indo-ish physical appearance, b) western-ish white colour, c) utilization of English; 2) the phenomena is the result of strong construction over colonialism syndrome, 3 ) the strategy to overcome the problem is by developing awareness towards local culture and national identity.

Currently, tracking of reference about the advertisement with Sundanese carried out through discourse study, specifically through critical discourse analysis is not available. Study on the advertisement with Sundanese using the critical discourse analysis is expected to complete similar researches with local language and culture.

\subsection{Theory}

Renkema [9] and Kress and van Leeuwen [10]explained the superstructure in the newspaper discourse. The Superstructure consists of a main (headline), introduction (lead), and body (flat text). The headline is sometimes followed by a subtitle which is a short explanation of the news, then the introduction (lead) which contain the main content of the news, and then the body (flat text). The body (flat text) contain the news itself. The superstructure in an advertisement is explained in detail by Leech (1966) which was implemented by Mardjadikara [11]. In an advertisement, the superstructure is consisted of title (headline), visual element, body of the advertisement (body copy), image of the product, and information (baseline).

Bierley [12] explained about positioning. Through positioning, the measured reason ("scientific reason") will be determined to motivate the prospective consumer of a product. The purpose of positioning is to ensure that the communication process to the consument is going well, to determine the advertisement target and marketing campaign, and to measure and estimate the society's behavior needed to penetrate the culture diversity. Moreover, positioning has a quite strong relationship with the concept of brand positioning. The position of a brand (brand positioning) provide additional value and interest among the similar kind of products. Sometimes, brand positioning describe how the position of product to the consumer's perspective. Fletcher [13] explained the criteria of a brand could achieve success if it take brand positioning into account. Brand positioning is chosen and carried out to exhibit the difference from the similar products. Brand positioning is chosen for several purposes, including to launch 
a completely new brand, to launch a new brand as the expansion of the previously existed brand, to make people aware on the existence of the brand, to persuade the people who has known the brand to try, to persuade the ex user of the brand to try it again, to persuade the brand user to use it more frequently, to persuade the user to use it in the different way, to persuade another target-teenagers or health keeper group-to use the brand, to persuade the retailer to keep the inventory so the community can get it.

\section{RESULTS AND DISCUSSION}

\subsection{Suprastructure}

Through the suprastructure, the advertisement of Kopi ABC Susu can be described by the following elements: title of advertisement, audiovisual or visual element, body copy, and some additional information of the advertisement.

Table 1. Suprastructure of Kopi ABC Susu advertisement

\begin{tabular}{|c|c|}
\hline ELEMENT & \\
\hline Title of advertisement (headline) & (Kopi ABC Susu) \\
\hline \multicolumn{2}{|l|}{ Audiovisual element } \\
\hline \multicolumn{2}{|l|}{ Visual element } \\
\hline Body copy & $\begin{array}{l}\text { eta mah susu dikupian } \\
\text { mun kopi abc susu } \\
\text { tah ieu kupi disusuan }\end{array}$ \\
\hline Product image & reses \\
\hline \multicolumn{2}{|l|}{ Information (baseline): } \\
\hline Logo & 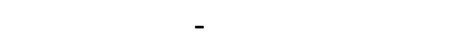 \\
\hline Audiovisual slogan & kopi susu yang bener-bener kopi \\
\hline Visual slogan & - \\
\hline Company name & - \\
\hline
\end{tabular}

The title of the advertisement is not written explicitly, but it is well known that the title is Kopi ABC Susu. The advertisement of this coffee products actually had been known by the public previously in Indonesian. Along with the marketing process, the advertisement was 
transliterated to Sundanese but contain the same information which had been widely known by the publik of Indonesia. The transliteration is an effort carried out by the producer to emphasize the product image at any society groups and at any market segment of coffee connoisseurs.

In the visual element, there was a clear difference between the visual and audiovisual elements. The visual display of the advertisement was placed on the left side of the web page, filled with the body copy in bold capital letters with variation of font size. Textually, the body was written in three lines, including the category of the advertisement with short copy. The first and third lines of text had the same font size. The text in the first line was ETA MAH SUSU DIKUPIAN (1a) and the third line was "TAH IEU KUPI DISUSUAN (1c). The font size for the text MUN KOPI ABC SUSU (1b) in the second line was bigger than the first and the third lines. The text in the first and the third lines were texts with contradictory meaning which showed a debate between both lines.

(1a) Eta mah susu dikupian "That is milk added with coffee"

(1c) Tah ieu kupi disusuan 'This is coffee added with milk'

Based on the words arrangement, the old information was milk. Milk is the basic material for the beverage, then coffee is added as the blend. The segment which likes this beverage is commonly called as coffee connoisseurs, never called as milk connoisseurs. Thus, the highlighted representation is the coffee connoisseurs, both for pure coffee or coffee with additional flavor. However, coffee with milk blend is more accepted by the coffee connoiseurs (1c). The contradictory between the irregularity (1a) and regularity (1c) was corrected by the existence of Kopi ABC Susu product (1b). The more flexible coffee connoisseurs will open their mind to accept the coffee product blended with other compound, in this case the milk. There is a possibility that the consumer who do not like or have not known about coffee will begin to get interested to enjoy coffee with "light taste", thus the appearance of Kopi $\boldsymbol{A B C} \boldsymbol{S u s u}$ product (1b) become the oportunity to know the taste of coffee through milk dishes.

In the audiovisual broadcast, there was a different on the vocal pressure between $(1 \mathrm{a}, \mathrm{c})$ and (1c). The vocal of the speaker was stronger and louder in (1b). The emphasis showed that the dominance of the product is more primary than the debate on the taste (1a) and (1c).

/// ^ eta mah / susu dikupian // mun / kupi ABC susu // tah / ieu / kupi / disusuan ///

The layout of the text was placed on the left side of the reader rather then the right side. There is a probability that the readers of text with left to right pattern will firsly watch the objects placed on the left side rather than the right side of the pictrure. The visual image was placed on the right of the picture, where a clear cup shows the product, while at the right side of the cup, the image of product in sachet is placed. Thus, the product is introduced by picture. The comparison on the size of the clear cup and the sachet was 1:1, showing that the importance of display and content is similar. In this advertisement, the package was placed inside the clear cup expecting the prospective consumer to see directly the sample of the product content. The color was not as dark as black coffee, but not as white as milk too. The combination of chocholate milk color wa presented in the image. It represented that the taste was not as strong as coffee, but light, consumeable by the beginner of coffee connoisseurs.

At the baseline, thre was a slogan, an audiovisual broadcast with 5 seconds length. The slogan showed up the 0.00:05 second coincide with the end of the advertisement. The slogan "KOPI SUSU YANG BENAR-BENAR KOPI" supported the body, emphasize the purenes of the taste of cofee even though it was blended with another taste, in this case the milk. The 
composition between coffee and milk was maintained perfectly by the producer so that the taste of coffee still dominate the product. The emphasis was further supported by the text placed on the text block with bright color, red. The setters carried out further emphasis by using the red colored text outline in bold capital letters filled with white color. A slogan which ensure the (prospective) consumer through the utilisation of challenging background color on the text block, which was contrast to the white color for the letters. The display of the slogan showed the courage to accept new challenge, coffee blended with another taste. The yellowish-orange was put as the backround of the diplay. According to the popular psychological expert, warm beverage such as coffeee, tea, and milk are more delicious while served in the orange colored container. Overall, the music and vocal of the speaker in the advertisement broadcast were spiritful to try new thing, coffee with milk taste.

\subsection{Positioning}

Thera are a lot of coffee advertisement in Indonesian along with the growth and diversed coffee product widely distributed in every region in nusantara. No wonder that more than 100 coffee products existed in Indonesia, started from the product with traditional and simple packaging,to the modern and elegant packaging. Each product has its peculiarity on the taste, color, shape, serving, etc. Because of the number and variety of coffee product in Indonesia, a precise and unique handling of positioning is required in order to escape the term "ordinary" or "not special". It can simply be traced from the slogan of each coffee product. Coffee with various quality can be found in Indonesia. However, the slogan of coffee can be devided into pure cofee and blended coffee. Related to the coffee blend with milk taste, similar product is also existed in another brand with identic slogan, such as Kapal Api Kopi Susu with "Kopi Susunya Lebih Enak", Kopi ABC with the slogan "Kopi ABC, Mantap kopinya, mantap susunya" or "Kopi ABC Susu, Kopi Susu yang Benar-benar Kopi”, Kopi Susu Ya with the slogan "Kopi Susu Ya, Kopi Nikmat, Harga Bersahabat" or "Kopi Susu Ya, Sruput Nendang”, Torabika Susu Full Cream with the slogan "Nikmatnya full gak setengah-setengah", Torabika Susu with the slogan "Pas Kopinya, Pas Susunya" or "10\% mantap kopi, 100\% gurihnya susu.

Positioning method according to Kasali [14] includes the difference on the products, the advantages of the products, competitors, imagination, and problems. The positioning method carried out by Kopi ABC Susu through the imagination which tickle the consumer candidate. Tickle is one of advertisement technique [6] Typical offer in almost all of the coffee blending products surely will not get a place in the consumer's mind. The strategy used by Kopi $\boldsymbol{A B C}$ Susu is including the utilization of local language and culture. Enjoying coffee is the lifestyle of the society in Nusantara, including Sunda. Enjoying milk is also the lifestyle of Nusantara society. Until now, milk is also used in tea blend, thus in some region blending tea (milk tea) is a lifestyle of the society. The problem is, the competition of milk tea advertisement is not intense, while the coffee milk is.

Purposely, the advertisement creator want to develop a lifestyle that cofee is men's beverage. Based on the intertextual study to another coffee product Best Bali "Kopinya lelaki sesungguhnya" or implicitly in the advertisement of Indocafe cappuccino with its slogan "ngenumero uno" advertised by international level MotoGP racer Valentino Rossi. Racer is strongly identic to or collocated with man. Thus, coffee is interpreted as an expression of superior men's taste. 


\section{CONCLUSION}

The study about advertisement which use some approaches, begun with the analysis of superstructure and positioning of the advertisement. The holistic approach to the advertisement reveals how the myth and hegemony to be achieved. This should be followed by the help of intertextual study.

\section{SOURCES OF DATA}

Advertisement of Kopi ABC Susu https:/www.youtube.com/watch?v=wORul7MLH-w (0.00:05) and https://i.ytimg.com/vi/wORul7MLH-w/hqdefault.jpg

\section{ACKNOWLEDGEMENT}

Supporting agencies Hibah PITTA 2018

\section{REFERENCES}

[1] P. Brooks, Writing Advertising Copy How to Write Winning Copy that Boosts Response Rates and Gets Results. Hampshire: Rowmark, 2002.

[2] A. Goddard, The Language of Advertising Written Texts. London \& New York: Routledge, 1998.

[3] M. Ngafenan, Kamus Etimologi Bahasa Indonesia. Semarang: Dahara Prize, 1990.

[4] R. Jones, Loan-words in Indonesian and Malay. Jakarta: KITLV Jakarta dan Yayasan Obor Indonesia, 2008.

[5] J. I. Richards and C. M. Curran, "Oracles on 'Advertising': Searching for a Definition," J. Advert., vol. 31, no. 2, pp. 63-77, Jun. 2002.

[6] G. Cook, The Discourse of Advertising. London \& New York: Routledge, 2001.

[7] Rajiyem and W. A. Setianto, "Konstruksi Budaya dalam Iklan: Analisis Semiotik terhadap Konstruksi Budaya dalam Iklan Viva Mangir Beauty Lotion,” J. Hum., vol. 16 , no. 2, pp. 155-167, 2004

[8] K. Kasiyan, "Hegemoni Estetika Postcolonial dalam Representasi Iklan di Media Massa Cetak Indonesia Kontemporer," J. Hum., vol. 24, no. 3, pp. 292-302, 2012.

[9] R. Renkema, Introducing to Discourse Studies. Amsterdam/Philadelphia: John Benjamin, 2004.

[10] G. Kress and T. van Leeuwen, Reading Images The Grammar of Visual Design. London \& New York: Routledge \& Taylor and Francis Group, 2006.

[11] A. S. Madjadikara, Bagaimana biro iklan memproduksi iklan. Jakarta: PT Gramedia Pustaka Utama, 2004.

[12] S. Brierley, The Advertising Handbook. London \& New York: Routledge, 1995.

[13] M. Moke, "Political Advertising in Chile," in The SAGE Handbook of Political Advertising, Thousand Oaks, CA: SAGE Publication, 2006.

[14] R. Kasali, Membidik Pasar Indonesia: Segmentasi, Targeting, dan Positioning. Jakarta: Gramedia Pustaka Utama, 1998. 